\title{
Pengembangan Protokol Isolasi DNA Genom Tanaman Durian Dengan Menggunakan Modifikasi Bufer CTAB
}

\author{
Sundari \\ 1,2Pendidikan Biologi, Universitas Khairun, Ternate \\ ${ }^{*}$ Corresponding authors: e-mail: sundariunkhair08@gmail.com \\ Manuscript received: 27-07-2017 Revision accepted: 22--09-2017
}

\begin{abstract}
Abstrak
Protokol dan metode sederhana, efisien untuk isolasi DNA genom tanaman durian yang banyak mengandung phenol dan residu polisakarida telah dihasilkan. Pada penelitian ini, digunakan protokol isolasi DNA tumbuhan dengan metode CTAB yang dimodifikasi sebagai protokol yang efisien untuk membuang polisakarida, phenol dan lendir yang sangat melimpah pada tanaman durian. Obyek penelitian ini terdiri dari protocol CTAB yang dimodifikasi tahap inkubasi dan presipitasi pemurnian DNA genom dari phenol dan polisakarida. Perbandingan 2 protokol isolasi DNA durian dengan CTAB standard an CTAB modifikasi menunjukkan bahwa metode CTAB modifikasi menghasilkan whole genom durian cukup murni rata rata 1,99 dan berhasil diamplifikasi dengan PCR-RAPD.
\end{abstract}

Kata kunci: isolasi, DNA, polisakarida, CTAB, modifikasi, .

\section{Abstract}

The simple and efficient method for genomic DNA isolation protochol from durian, its woody fruit crops containing high polysaccharide levels has been described here. In the present study, using modified CTAB for plant DNA isolation protocols were studied for removing the highly concentrated polysaccharides from genomic DNA of woody fruit crops. This method involves the modified CTAB at the incubate and precipitate procedure employing DNA purification step to remove polysaccharides and phenol residu. Compared with the two studied DNA isolation protocols of durian using standart CTAB and modified $\mathrm{CTAB}$ the everage yield high quality DNA whole genom is 1,99 purity and DNA was suitable for PCR and RAPD analyses.

Keyword: isolation, DNA, polysaccharides, phenol residu, CTAB

\section{PENDAHULUAN}

Salah satu upaya dalam program pemuliaan tanaman buah tropis di Indonesia pada saat ini adalah kajian keanekaragaman dan kekerabatan genetic. Diharapkan melalui kajian ini dapat diketahui jarak genetic untuk digunakan sebagai acuan dalam persilangan antar kerabat sehingga diperoleh sifat unggul. Beberapa jenis buah tropis yang menjadi focus program pemuliaan tanaman adalah : mangga (Mangifera indica L.) jeruk (Citrus spp.), Leci (Litchi chinensis 
S.), sirsat (Annona squasoma L.), jambu (Pisidium guajava L.),pisang (Musa spp.), delima (Punica granatum L) Jojoba (Zizypus mauritiana M.), papaya (Carica papaya L.), Nanas (Ananas comosus L.) dan durian (Durio zibethinus). Sebagian besar tanaman ini merupakan jenis tanaman tahunan, berkayu, dan mengandung banyak komponen polysaccharida.

Isolation DNA dengan kualitas tinggi merupakan hal yang esensial dalam riset molekuler dan keanekaragaman genetic. Kontaminasi Polysaccharida merupakan salah satu problem dalam kegiatan isolasi DNA pada tanaman berkayu. Sampel DNA dari tanaman berkayu sering terkontaminasi oleh polisakarida, fenol, dan derivatnya yang sangat mengganggu kualitas DNA genom yang dihasilkan (Fang et al. 1992; Porebski et al. 1997; Schlink and Reski 2002), Kualitas DNA genom yang dihasilakan selama isolasi akan mempengaruhi daya simpan DNA dan munculnya enzim dan inhitor pada saat tahap amplifikasi DNA dan sekuensing (Lodi et al.1994; Sharma et al. 2002).

Cetyl Trimethyl Ammonium Bromide (CTAB) merupakan metode yang umum digunakan dalam ekstraksi DNA genom tanaman yang banyak mengandung polisakarida dan senyawa polifenol (Lumaret et al. 1998; Jose dan Usha 2000). Ada tiga langkah utama dalam ekstraksi DNA, yaitu perusakan dinding sel (lisis), pemisahan DNA dari bahan padat seperti selulosa dan protein, serta pemurnian DNA (Nicholl 1993; Surzycki 2000). Protokol isolasi DNA pada saat ini sudah banyak dikembangkan namun protocol tersebut masih bersifat universal bagi tanaman atau hewan dan mikroorganisme. Beberapa protocol isolasi DNA dalam paket miniprep kit DNA extraction untuk tanaman sudah dilengkapi dengan bahan dan kolom pembersih polisakarida (Porebski et al. 1997; Schlink and Reski 2002).

Pada beberapa jenis tanaman buah tropis masih sangat sulit memisahkan kontaminan polisakarida dan derivatnya selama proses isolasi DNA sehinnga proses amplifikasi DNA dengan PCR - RAPD, RFLP maupun SSR menghasilan pita DNA yang sangat sedikit bahkan ada yang gagal dalam amplifikasi DNA (Luro et al. 1995; .Porebski et al. 1997). Tujuan penelitaian ini adalah untuk megembangkan teknik isolasi DNA genom dari tanaman durian yang merupakan tanaman berkayu dan berlendir tinggi dimodifikasi dari protocol CTAB standar, modifikasi difokuskan pada menghilangkan kontaminan residu fenol dan polisakarida dari DNA melalui presipitasi PCI dan penamjangan waktu inkubasi.

\section{BAHAN DAN METODE}

Bahan yang digunakan adalah sampel daun muda tanaman durian lokal asal Ternate. Bahan lain yang digunakan adalah Nitrogen cair, Bufer CTAB CTAB (CTAB: 4,1 g NaCl, 10 g CTAB, 0,5 M EDTA $\mathrm{pH} 8,0,18,61 \mathrm{~g}$ disodium etilendiamin tetra asetat $2 \mathrm{H} 2 \mathrm{O}, 1 \mathrm{M}$ Tris- $\mathrm{HCl} \mathrm{pH} 8,0,12,11$ g Trisma Base, 1,40 M NaCl, 29,22 g sodium khlorida, 2\% PVP dan 0,20\% ß-mercaptoetanol)., pvp, 
ß-mercaptoetanol, buffer TE, buffer EDTA, befer TBE, primer RAPD 1-5 yang mempunyai untaian nukleotida RAPD1, RAPD2, RAPD3, RAPD4, RAPD5, RAPD6, 3000 kb DNA ladder.

\section{Prosedur isolasi DNA Genom}

Isolasi DNA genom dari sampel daun durian lokal Ternate menggunakan metode CTAB (Doyle \& Doyle, 1990 dan metode CTAB yang dimodifikasi peneliti). Sebanyak 0,05 gram daun segar digerus dengan mortal pistil steril dengan nitrogen cair dan ditambahkan buffer ekstrak \{CTAB $2 \%, 1 \mathrm{M}$ Tris- $\mathrm{HCl}(\mathrm{pH} 8), 0,5 \mathrm{M}$ EDTA ( $\mathrm{pH}$ 8), $5 \mathrm{M} \mathrm{NaCl}, 7,5 \mathrm{M}$ Amonium sulfat, dan 0,1 mg/ $\mu \mathrm{L}$ RNAse \} kemudian ditambahkan $2 \% \beta$ mercaptoetanol, dan selanjutnya inkubasi suhu $60{ }^{\circ} \mathrm{C}$ selama 30 menit, kemudian di sentrifuse pada suhu $4^{\circ} \mathrm{C}$, $13.000 \mathrm{rpm}$ selama 10 menit, Supernatan ditambahkan PCI (phenol: Chloroform: Isoamilalkohol) 25:24:1 dan disentrifuse pada suhu $4^{\circ} \mathrm{C}, 13.000 \mathrm{rpm}$ selama 10, selanjutnya supernatan ditambah dengan $\mathrm{CI}$ (chloroform:Isoamilalkohol) 24:1dan disentrifuse pada suhu $4^{\circ} \mathrm{C}, 13.000 \mathrm{rpm}$ selama 5 menit, supernatan dipindahkan ke tabung ependof baru dan ditambahkan amonium sulfat 7,5M sebanyak 0,1 volume supernatan mixgentle dan ditambahkan alkohol absolut sebanyak 2,5 volume supernatan dan dikocok, selanjutnya diinkubasi pada suhu $-20{ }^{0} \mathrm{C}$ selama 2 jam, selanjutnya sentrifuge selama 15 menit pada suhu $4^{\circ} \mathrm{C} 13.000 \mathrm{rpm}$, kemudian supernatan dibuang dan pelet ditambah alkohol $70 \%$ sebanyak $500 \mu \mathrm{L}$ dan disentrifuse selama 15 menit, buang supernatan dan pelet dikeringanginkan selama 1 jam selanjutnya ditambahkan buffer TE (pH 8) sebanyak $50 \mu \mathrm{L}$ dan DNA durian siap disimpan pada suhu $-20^{\circ} \mathrm{C}$ untuk jangka waktu lama.

Catatan : modifikasi CTAB yang dilakukan peneliti adalah modifikasi :1) Konsentrasi Bufer CTAB menjadi 3\%; 2) konsentrasi $\beta$ mercaptoetanol menjadi 3\%; 3) waktu inkubasi suhu $60^{\circ} \mathrm{C}$ dengan $3 \% \beta$ mercaptoetanol diperpanjang menjadi 180 menit; 4) proses pencucian dengan PCI menjadi 3- 4 kali cuci, dan 5) inkubasi suhu -20ㄷ menjadi 18 jam.

\section{Kuantifikasi DNA Menggunakan Elektroforesis}

DNA dikuantifikasi menggunakan elektroforesis pada agarose gel $1,5 \%$. Prosesnya, $1 \mu 1$ stok DNA dicampur dengan $9 \mu$ air suling dan $2 \mu$ loading dye. Campuran contoh lalu dimasukkan ke dalam sumuran gel dalam kamar elektroforesis yang telah diisi bufer TBE 1x (Trisma Base, boric acid, dan 0,5 M EDTA $\mathrm{pH}$ 8,0). Sebagai pembanding digunakan marker DNA ladder yang diletakkan pada sumur pertama kemudian elektroforesis dijalankan pada tegangan 70 volts sampai DNA bermigrasi/bergerak lebih kurang $1 \mathrm{~cm}$ di atas batas bawah. Selanjutnya visualisasi dengan GelDoc Uvtransluminator, sedangkan uji kuantitatif dilakukan dengan mengukur konsentrasi dengan spektronanodrop.

\section{Amplifikasi RAPD PCR}

Reaksi amplifikasi DNA dengan menggunakan PCR merk Takara. Jumlah koktail PCR yang digunakan adalah $10 \mu \mathrm{L}$ dengan komposisi $5 \mu \mathrm{L}$ PCR mix merk INTRON; $3 \mu \mathrm{L} \mathrm{DdH} \mathrm{D}_{2} \mathrm{O} ; 1 \mu \mathrm{L}$ 
primer OPA (1, dan 19) dan $1 \mu \mathrm{L}$ DAN template. Pengaturan program PCR yang digunakan adalah sebanyak 45 siklus yang terdiri dari fase Pradenaturasi suhu $94^{\circ} \mathrm{C}$ selama 5 menit; Denaturasi suhu $94^{\circ} \mathrm{C}$ selama 30 detik; Anealing suhu $37^{\circ} \mathrm{C}$ selama 30 detik; Ekstensi suhu $72^{\circ} \mathrm{C}$ selama 90 detik; dan Post Ekstensi suhu $72^{\circ} \mathrm{C}$ selama 7 menit. Selanjutnya dilakukan tahap elektroforesis untuk visualisasi hasil amplifikasi DNA durian menggunakan penanda molekuler RAPD dengan menggunakan 2 primer (Tabel 1). Untuk membandingkan ukuran pasang basa antar pita DNA hasil amplifikasi digunakan marker DNA 1000bp plus merk INTRON.

Tabel 1. Sekuen primer OPA

\begin{tabular}{cc}
\hline Primer & Seq $\mathbf{5}$ to $\mathbf{3}$ \\
\hline OPA-1 & CAG GCC CTT C \\
OPA-19 & CAA ACG TCG G \\
\hline
\end{tabular}

Selanjutnya hasil PCR, di elektroforesis dengan dimasukkan dalam sumuran gel 1,5\% dalam kamar elektroforesis yang sudah diisi bufer TBE 1x, diisikan satu sumuran pertama dengan 3000 bp DNA ladder.Setelah itu elektroforesis dijalankan dengan daya 70 volt sampai penanda loading dye berada sekitar $1 \mathrm{~cm}$ di atas batas gel bagian bawah.

\section{HASIL DAN PEMBAHASAN}

Data hasil penelitian ini berupa profil DNA genom tanaman durian hasil isolasi dengan menggunakan protocol isolasi DNA CTAB (Doyle \&Doyle, 1990) dan CTAB modifikasi seperti gambar 1 dan 2 berikut:

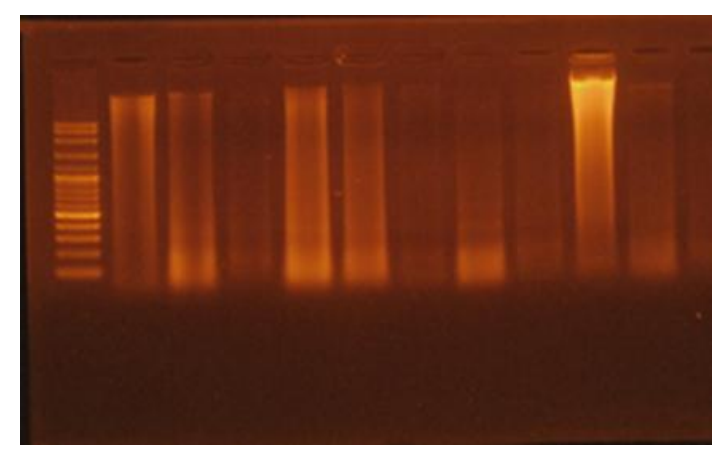

Gambar 1: DNA durian (metode CTAB)

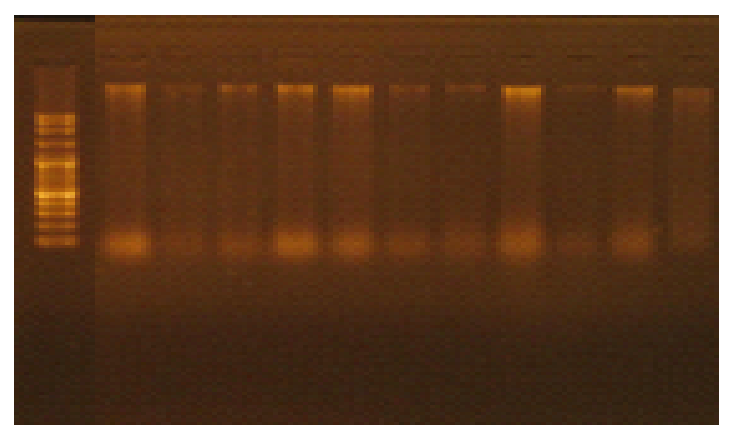

Gambar 2: DNA durian (CTAB modifikasi)

Profil DNA genom tanaman durian dengan protocol CTAB (Doyle\&Doyle, 1990) (gambar 1) Nampak bahwa DNA genom yang dihasilkan pada 10 sampel tanaman durian mengalami smear dan DNA yang dihasilkan sangat tipis. Pada gambar 2 nampak bahwa DNA genom yang dihasilkan dengan protocol $\mathrm{CTAB}$ modifikasi lebih tebal di atas namun masih terdapat sisa kontaminasi RNA di bawah. Selanjutnya data konsentrasi dan kemurnian DNA seperti pada table 2 berikut: 
Sundari. ISOLASI, DNA, POLISAKARIDA, CTAB, MODIFIKASI

Tabel 2. Data Kemurnian DNA Genom pada tanaman durian

\begin{tabular}{|c|c|c|c|}
\hline Nomor & Sampel & $\begin{array}{c}\text { Komurnian } \\
\text { (metode CTAB) }\end{array}$ & $\begin{array}{c}\text { Kemurnian } \\
\text { (CTAB modifikasi) }\end{array}$ \\
\hline 1 & T1 & 2,10 & 1,79 \\
\hline 2 & $\mathrm{~T} 2$ & 2,13 & 1,90 \\
\hline 3 & T3 & 0,99 & 1,99 \\
\hline 4 & $\mathrm{~T} 4$ & 2.44 & 1,99 \\
\hline 5 & T5 & 2.11 & 2,01 \\
\hline 6 & T6 & 1,01 & 2,02 \\
\hline 7 & $\mathrm{~T} 7$ & 1,02 & 2,05 \\
\hline 8 & $\mathrm{~T} 8$ & 1,01 & 1,99 \\
\hline 9 & T9 & 2,10 & 1,02 \\
\hline 10 & T10 & 1,20 & 1,89 \\
\hline
\end{tabular}

Hasil isolasi DNA genom tanaman durian dengan metode isolasi dengan CTAB menghasilkan DNA dengan kemurnian yang rendah artinya masih terdapat kontaminasi polisakaridasi dan phenol. Kemurnian DNA genom hasil isolasi dengan protocol CTAB modifikasi menunjukkan nilai yang mendekati DNA murni yaitu 1,90. DNA yang mengandung basa purin dan pirimidin dapat menyerap cahaya UV. Pita ganda DNA dapat menyerap cahaya UV pada $260 \mathrm{~nm}$, sedang kontaminan protein atau phenol dapat menyerap cahaya pada $280 \mathrm{~nm}$. Dengan adanya perbedaan penyerapan cahaya UV ini, kemurnian DNA dapat diuji secara kuantitatif dengan menghitung nilai absorbansi $260 \mathrm{~nm}$ dibagi dengan nilai absorbansi $280 \mathrm{~nm}$ (Aras, dkk., 2003). Kemurnian DNA ditentukan dengan estimasi rasio absorbansi pada $260 \mathrm{~nm}$ sampai $280 \mathrm{~nm}(\AA$ 260/ Å 280), dan nilai kemurnian DNA berkisar antara 1,8-2,0. (Sambrook, 2001).

Pada umumnya isolasi DNA pada tahap awal menggunakan nitrogen cair untuk melisis dinding sel dapat mengeluarkan semua isi sel, selanjutnya ditampung dalam larutan penyangga yang berisi Tris $\mathrm{HCl}$ dan EDTA. Namun dinding sel juga dapat dipecahkan dengan penggerusan menggunakan bufer ekstraksi diikuti dengan penghangatan pada suhu $65^{\circ} \mathrm{C}$. Bahan detergen seperti sodium dodecil sulfat (SDS), sarkosil, dan CTAB dapat digunakan untuk proses lisis (Subandiyah ,2006). Penggunaan bufer CTAB sebagai pengganti nitrogen cair untuk ekstraksi dapat menghasilkan produk DNA yang berkualitas yang ditunjukkan oleh pita DNA genom (Gambar 1 dan 2). Produk isolasi DNA yang berkualitas baik ditunjukkan dengan pita DNA yang terlihat tebal dan bersih bila divisualisasi menggunakan gelDoc elektroforesis. Setelah proses elektroforesis DNA genom dan dihasilkan pita DNA yang berkualitas dilanjutkan proses PCR, yaitu metode in vitro yang secara cepat dapat mengcopi sekuen-sekuen DNA target yang ada di dalam whole genom DNA. Selanjutnya dilakukan amplifikasi DNA dengan menggunakan PCR-RAPD dengan 2 primer OPA 1dan OPA 19. Hasil amplifikasi DNA seperti gambar 3 dan 4 berikut: 

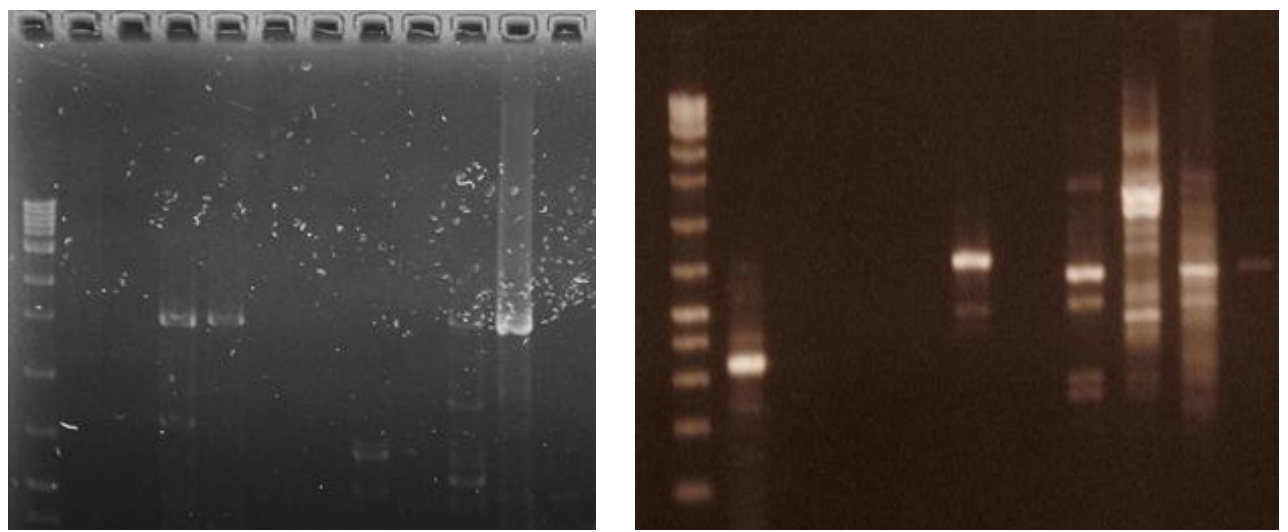

Gambar 3 : Profil RAPD Polimorfisme dari 10 sampel durian dengan primer OPA 1 (gambar kiri ); dan OPA 19 (gambar kanan)

Profil DNA genom hasil amplifikasi PCR-RAPD dengan metode CTAB modifikasi seperti gmabar 4 berikut:
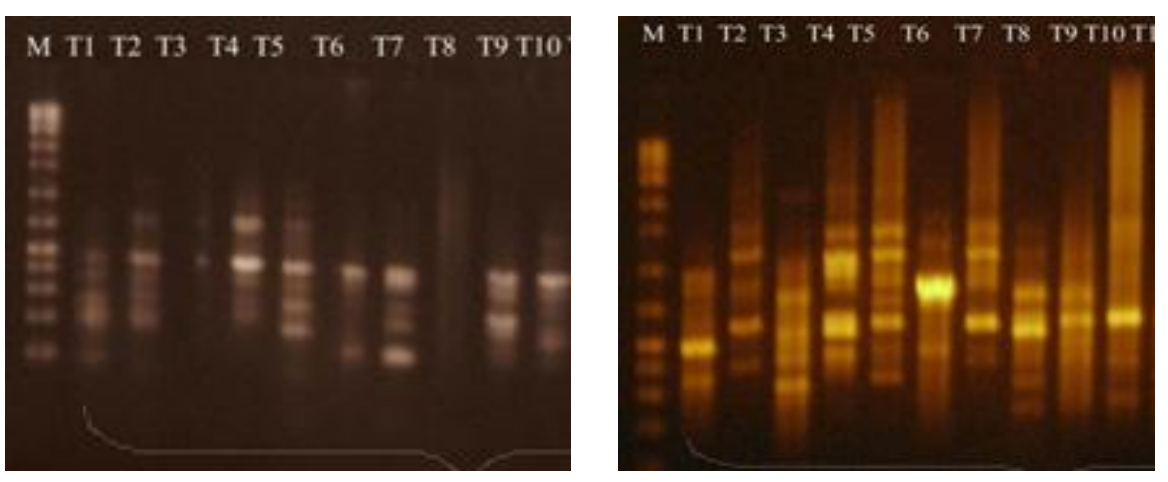

Gambar 4 : Profil RAPD Polimorfisme dari 10 sampel durian dengan primer OPA 1 (gambar kiri ); dan OPA 19 ( gambar kanan)

PCR-RAPD menunjukkan bahwa protocol standar CTAB tidak efektif untuk proses amplifikasi DNA durian, hal ini dapat dilihat pada gambar 3 pita DNA yang terbentuk pada primer OPA 1 sangat jarang hamper tidak ada, sedangkan pada penggunaan OPA 19 terdapat 5 sampel DNA yang dapat teramplifikasi dan sisanya kosong. Pada produk PCR-RAPD dengan menggunakan protocol CTAB modifikasi diketahui pada primer OPA 1terdapat 9 sampel DNA yang berhasil teramplifikasi dan pada primer OPA 19 terdapat 10 sampel DNA yang teramplifikasi. Produk PCR akan menjadi DNA awal. Sekitar 105 kopi dari sekuen DNA target dengan mudah dapat divisualisasikan sebagai pita diskret dengan ukuran spesifik ketika diseparasi pada elektroforesis gel agarose (Tridjatmiko, 2006).

Teknik Random Amplified Polymorphic DNA (RAPD) yaitu teknik pengujian polimorfisme DNA berdasarkan pada amplifikasi dari segmen-segmen DNA acak yang menggunakan primer tunggal yang sekuen nukleotidanya ditentukan secara acak. Primer tunggal ini biasanya berukuran 10 basa. PCR dilakukan pada suhu anealing yang rendah yang memungkinkan 
primer menempel pada beberapa lokus pada DNA. Aturan sederhana untuk primer adalah terdiri atas 18- 28 susunan basa dengan persentase G+C 50-60\% (Subandiyah, 2006).

Pola pita DNA tanaman durian yang dihasilkan dari isolasi DNA menggunakan CTAB standar disajikan pada Gambar 3, sedangkan hasil isolasi DNA tanaman durian dengan menggunakan protocol CTAB modifikasi bufer yang berisi 3\% CTAB, $1 \mathrm{M} \mathrm{NaCl}, 3 \% \beta$-mercaptoetanol, dan $4 \%$ PVP 10 disajikan pada Gambar 4. Bila kedua gambar tersebut dibandingkan maka pola pita DNA yang dihasilkan memiliki ketebalan yang tidak sama. Dengan demikian, bufer CTAB modifikasi cukup memenuhi syarat untuk digunakan dalam isolasi DNA dari tanaman yang mengandung karbohidrat dan fenol tinggi karena tidak merusak DNA. Bufer CTAB dengan kandungan garam yang tinggi dapat memisahkan polisakarida dari dinding sel (Porebski et al. 1997; Surzycki 2000), sedangkan PVP dapat mengurangi broning akibat kandungan fenol pada daun muda (Porebski et al. 1997).

\section{KESIMPULAN}

Teknik isolasi DNA pada tanaman berkayu memerlukan protocol yang spesifik. Protocol tersebut dapat dikembanagkan dari protocol standar yaitu CTAB. Pemisahan DNA dari kontaminan seperti protein, lemak, dan karbohidrat dapat dilakukan saat isolasi dengan modifikasi konsentrasi bahan, waktu inkubasi dan teknik presipitasi. Penggunaan bufer CTAB ditambah 3\% $\beta$-mercaptoetanol dan PVP mampu mengurangi broning.

\section{UCAPAN TERIMAKASIH}

Penulis mengucapkan terimaksih tak terhingga kepada Dr. Yayuk Muliati, M.Si dan Abdu Mas'ud M.Pd yang telah membantu pelaksanaan isolasi DNA, pemotretan gelDoc dan analisis data molekuler PCR-RAPD selama penelitian.

\section{REFERENCES}

Aras, S., A. Duran \& G. Yenilmez. 2003. Isolation of DNA for RAPD Nalysis From Dry leaf Material of some Hesperis L. specimens. Plant Molecular Biology Reporter. 21: 461a- 461f

Doyle, J.J. and J.L. Doyle. 1990. Isolation of plant DNA from fresh tissue. Focus 12:13-15. Fang, G, S. Hammar and R. Grumet. 1992. A quick and inexpensive method for removing polysaccharides from plant genomic DNA. BioTechniques 13:52-57.

Fang G, Bammar S, Grumnet R. 1992. A quick and inexpensive method for removing polysaccharides from plant genomic DNA. Biofeedback 13: 52-54.

Jose, J. and R. Usha. 2000. Extraction of geminiviral DNA from a highly mucilaginous plant (Abelmoschus esculentus). Plant Mol. Biol. Rep. 18: 349-355. 
Lodhi MA, Ye GN, Weeden NF, Reisch BI. 1994. Simple and efficientmethod for DNA extractions from grape vine cultivars and Vitis species. Plant Mol Biol Rep 12: 6-13.

Luro FM, Lorieux JM, Laigret Bove, Ollitrault P. 1995. Genetic mapping of an integenric Citus hybrid using molecular markers. Fruit 49: 404-408.

Lumaret, R., H. Michaud, J.P. Ripoll, and L. Toumi. 1998. Chloroplast DNA extraction procedure for species high in phenolics and polysaccharides. p. 15-17. In A. Karp, P.G.

Nicholl, D.S.T. 1993. An Introduction to Genetic Engineering. Department of Biological Science, University of Praisly.

Porebski, S., L.G. Baily, and B.R. Baum. 1997. Modification of a CTAB DNA extraction protocol for plants containing high polysaccharide and polyphenol components. Plant Mol. Biol. Rep. 15: 8-15.

Porebski S, Bailey LG, Baum BR. 1997. Modification of a CTAB DNA extraction protocol for plants containing high polysaccharide and ployphenol components. Plant Mol Biol Rep 15: 8-15.

Isaac, and D.S. Ingram (Eds.). Molecular Tool for Screening Biodiversity. Chapman and Hall, London Schlink K, Reski R. 2002. Preparing high-quality DNA from Moss (Physcomitrella patens). Plant Mol Biol Rep 20: 423a-423f.

Sambrook J, Fritsch EF, Maniatis T. 1989. Molecular Cloning a Laboratory Manual.Edisi ke-2. Cold Spring Harbor Laboratory. New York Sharma AD, Gill PK, Singh P. 2002. DNA isolation from dry and fresh samples of polysaccharide-rich plants. Plant Mol Biol Rep 20: 415a- $415 f$.

Subandiyah, S. 2006. Polymerase Chain Reaction untuk Deteksi atau Identifikasi Patogen Tumbuhan. Beberapa Metode Ekstraksi DNA. Pelatihan dan Workshop Identifikasi DNAdengan Aplikasi PCR. Malang. hlm. 43-50.

Surzycki, S. 2000. Basic Techniques in Molecular Biology. Springer-Verlag, Berlin, Heidelberg, New York.

Tridjatmiko, K.R. 2006. Penggunaan Metode PCR untuk Deteksi Cepat Keragaman DNA. Pelatihan dan Workshop Identifikasi DNA dengan Aplikasi PCR. Malang. hlm. 22-25. 